\title{
A COMPARISON OF SOCIAL SKILLS OF STUDENTS WITH VISUAL IMPAIRMENTS AND TYPICALLY DEVELOPING STUDENTS*
}

\author{
Fatih Emrah Demir ${ }^{* 1}$, Selda Ozdemir ${ }^{2}$ \\ ${ }^{1}$ Res. Asst., Gazi University, Turkey, fatihemrah@gazi.edu.tr \\ ${ }^{2}$ Assoc. Prof., Gazi University, Turkey, seldaozdemir@gazi.edu.tr \\ ${ }^{*}$ Corresponding author
}

\begin{abstract}
The purpose of this study was to compare the social skills of students with visual impairments with social skills of typically developing students. The study groups consisted of 64 students with visual impairments and 68 typically developing students from the first to fourth grade. The Social Skills Rating System (SSRS) Teacher Form was used to evaluate the social skills of both groups. The results of the study indicated that cooperation, assertiveness, and self-control sub-scale scores and overall social skills scores of the students with visual impairments were statistically lower than the typically developing peers. The results of the study also indicated that age, gender and degree of visual impairments (having low vision or severe visual impairments) had no effect on the social skills of students with visual impairments. Findings of this study were discussed and suggestions for further research and practice were provided.
\end{abstract}

Keywords: Social skills, social skills deficits, visual impairments, low vision, severe visual impairments.

\section{INTRODUCTION}

Childhood is a period of development which should be associated with positive relationships in a supportive environment. However, some children may lack positive life experiences and therefore may be unable to develop appropriate social skills (Ozdemir, 2013). Children's social skills have been studied extensively in the literature. Thus, a variety of definitions of social skills exist. Ladd (1999) defined social skills as behaviours that linked to peer acceptance, positive friendship experiences and other positive relationship based outcomes. Social skills were also defined as a range of behaviours that are essential to one-on-one social interaction between individuals (McGuire \& Priestly, 1981).

An important concept related to students' social skills is social competence. Social skills and social competence are concepts which are very close to each other in regard to their meanings. However, both concepts are multidimensional and have different characteristics. According to Bacanli (1999) social skills and social competence symbolize different meanings. Social competence is a broader term when compared to social skills. Social competence is defined as the ability to function effectively across various social contexts (Dodge \& Murphy, 1984). While social skills comprise specific behaviours; social competence is a broader term which includes social skills. Therefore, while we regard an individual as a socially competent person, we give priority to the person's social skills observed across different settings and times. 
Merrill and Gimbel (1998) stressed three key points in defining social skills. These key points are peer acceptance, behavioural validity and social validity. Peer acceptance, the first key point, describes social skills as a popularity index. According to this viewpoint, if a person is popular among his/her peer group, he/she is competent in social skills. Behavioural validity, the second key point, underlies some behavioural processes such as reinforcements and punishments. The last key point, social validity stresses behavioural outcomes of social skills in different social contexts.

In a review study, Caldarella and Merrell (1997) examined twenty-one studies that examine social skills of children and adolescents. As a result of the study analysis, researchers addressed social skills with five dimensions. These five dimensions were peer relationships skills, self-control skills, academic skills, adaptive skills, and assertive skills. It is important to note that these dimensions of social skills cover social, developmental and cognitive domains.

Being socially competent is important for a child's social adjustment but also for adult's social adjustment as well. In adulthood, adults are expected to display positive social skills. Ceylan (2009) states that adults who gained sufficient social skills during their childhood period tend to have positive relations with others, could work cooperatively, are responsible for the rights and emotions of others, ask for help when necessary, refuse activities they do not want to participate, and maintain their lives as successful and happy.

Exhibiting age appropriate social skills in various social contexts helps people play an effective role and interact with others in effectively. If a person displays difficulties in exhibiting appropriate social skills, one may think that he/she displays social skills deficits. Strain and Odom (1986) divided social skills difficulties into two categories. The first category is social skills deficits and the other is performance deficits. If a person does not know how to display appropriate social skills in a social context, it could be called as a skill deficit. However, if one does know how to exhibit appropriate social skills but does not perform the skills consistently, this problem is considered as a performance deficit.

Social skills deficits may depend on age, gender and SES. Another factor that may contribute to social skills deficits is having a disability (Ozdemir, 2010). Many studies showed that children with special needs display social skills deficits (Buhrow et al., 1999; Sucuoglu \& Ozukcu, 2005). One of the special need populations that is at risk for social difficulties is children with visual impairments. Bandura (1986), a pioneer in the field, states that learning a new behaviour is a based on observing others, modelling and imitating observed behaviours. Students with visual impairments have limited observation skills (Raver, 1984), recognize less social reinforcements, and have limited imitation skills due to visual impairments. When compared to typically developing peers, individuals with visual impairments may display limited social skills because of receiving limited visual cues in regard to a social context (Farkas, Sherick, Matson, \& Loebig, 1981). Furthermore, students with visual impairments tend to be more passive when they are expected to display appropriate social skills (Harrell \& Strauss, 1986). As a result, they may exposure to peer rejection and minimal peer support (McAlpine \& Moore, 1995), exhibit verbal and non-verbal social skills deficits, need external support to interact with others (D’Allura, 2002), and display some isolated behaviour patterns (Buhrow et.al., 1998).

Researchers that examine the social skills of individuals with visual impairments in Turkey are very few. In general, studies that are conducted in Turkey indicated that social skills competencies of students with visual impairments were lower than their typically developing peers (Ozdemir, 2009; Ozdemir \& Ataman, 2010; Ozdemir et al., 2011; Ozkubat \& Ozdemir, 2012).

It is important to build the evidence base on designing effective interventions to address social needs of students with visual impairments in Turkey. Thus, studies that critically examine social skills needs of students with visual impairments with their peers are needed. As mentioned above, although there have been few important studies conducted in Turkey there should be more studies that lead to a better understanding for both researchers and professionals. In this study, authors attempted to contribute to the literature through examining and comparing social skills of students with and without visual impairments who are attending primary schools.

The purpose of this study was to compare the social skills of students with visual impairments with typically developing peers. The research questions of this study are:

1. Do social skills of students with visual impairments differ from their typically developing peers' social skills?

2. Do social skills of students with visual impairments differ in regard to students' grade levels?

3. Do social skills of students with visual impairments differ in regard to students' ages?

4. Do social skills of students with visual impairments differ in regard to students' genders? 
5. Do social skills of students with visual impairments differ in regard to the degree of students' visual impairments?

\section{METHOD}

A descriptive method was used in this study to compare the social skills of students with visual impairments and their typically developing peers. The Social Skills Rating Scale (SSRS) Teacher Form in Turkish (Gresham \& Elliot, 1990; Sucuoğlu \& Ozokcu, 2005) and a Personal Information Form were used to collect the study data. Data obtained from the SSRS Teacher form in Turkish and the Personal Information Form was analyzed. Initially, a reliability analysis was conducted for the Social Skills Scale that was used in this study and its subtests. After reliability analysis had showed that the Social Skills Scale and its subtests had been a reliable instrument to use in this study, statistical analysis was conducted. A Kolmogorov-Smirnov normality test was conducted for the Social Skills Scale and its subtest. Nonparametric tests were used as the Kolmogorov-Smirnov test did not support normality assumption. A Mann Whitney $U$ test was used to analyse whether there was significant difference between two independent groups. The Kruskal Wallis test was also used to analyse whether there was a significant difference between more than two independent groups.

\subsection{Participants}

The participants of this study were a total of 132 students, 64 students with visual impairments and 68 typically developing peers. The participants' ages ranged from 7 to 11 in both groups. All participants attended to primary schools in Ankara, capital city of Turkey.

In this study, there were two research groups. The first research group consisted 64 students with visual impairments and the second research group consisted 68 typically developing students. The distribution of the participants by age, gender, grade levels was shown on Table 1. The distribution of students with visual impairments by the degree of their visual impairments, having severe visual impairments or low vision, were also showed in Table 2.

Table 1. The distribution of the participants by age, gender, grade levels.

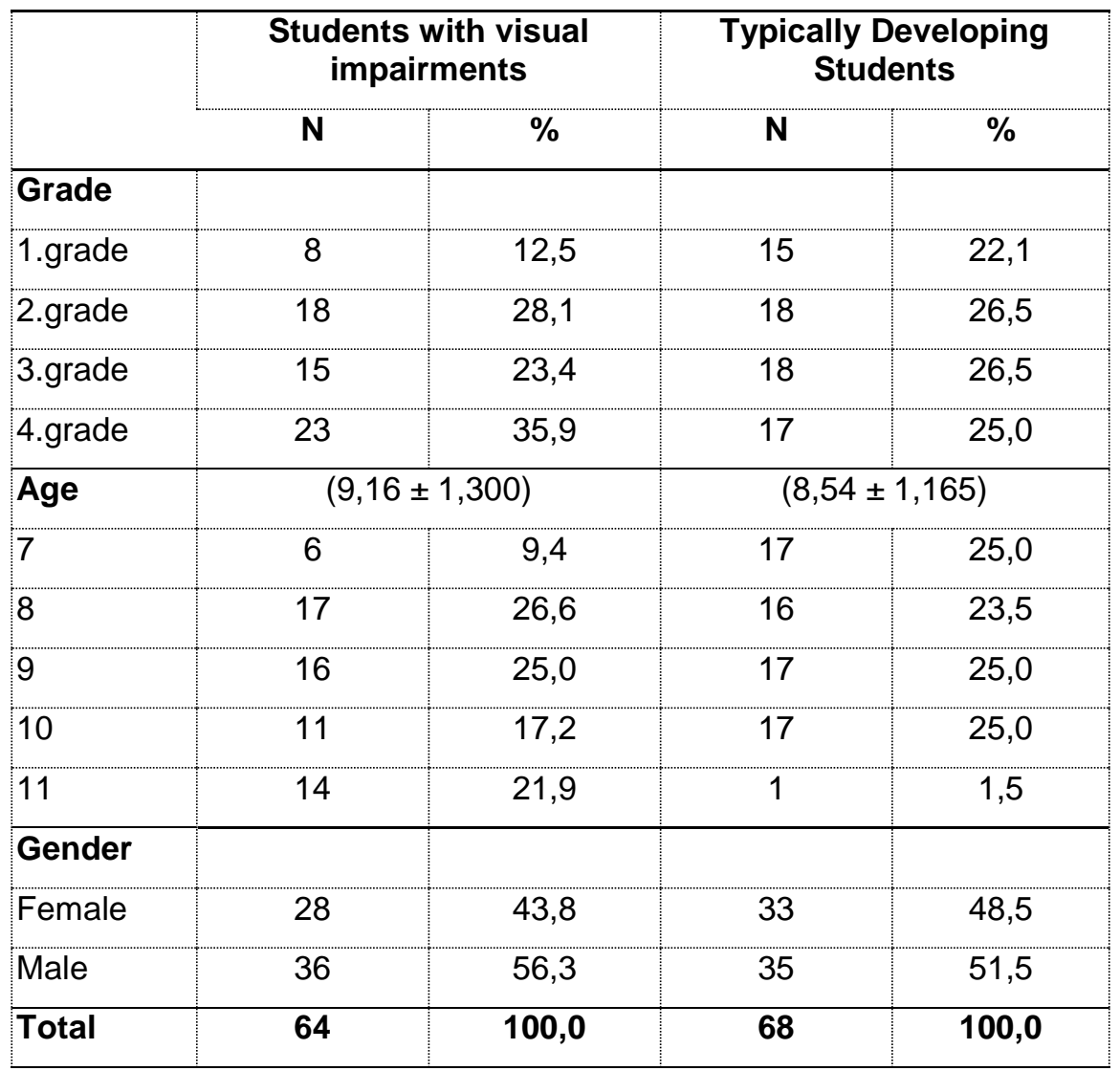

Table 1 shows the distribution of the participants by age, gender and grade levels in both groups. All participants were between the ages of 7 and 11 . Visually impaired group consisted 64 children and typically 
developing group consisted 68 children. There were 28 females, 36 male students in the visually impaired group and 33 female, 35 male students in the typically developing group. The mean age of visually impaired group was $9,16 \pm 1,3$. The mean age of typically developing group was $8,54 \pm 1,165$.

Table 2. The distribution of students with visual impairments by the degree of visual impairments.

\begin{tabular}{|l|c|c|}
\hline & N & $\%$ \\
\hline Degree of visual impairments & 30 & 46,9 \\
\hline Students with low vision & 34 & 53,1 \\
\hline Students with severe visual impairments & 64 & 100 \\
\hline Total & & \\
\hline
\end{tabular}

Table 2. shows that 30 participants of students with visual impairments had low vision. 34 participants of students with visual impairments had severe visual impairments. Overall students with visual impairments were 64.

\subsection{Procedure}

Teachers and school administrators from public elementary schools were contacted through field visits for the recruitment of the participant students. A permission letter, an official document, obtained from the Republic of Turkey Ministry of National Education were provided to the teachers and school administrators. Teachers were informed that they could participate in this study if they are volunteer.

Research procedure was clearly explained to both teachers and school administrators. When they had questions related to the study, the researchers answered their questions. Meetings with the teachers were arranged to make the research procedure clear. In this meetings, the Social Skills Rating Scale and its use were presented by the authors. A random sampling technique was employed for the selection of the sample group of typically developing children. Teachers of typically developing students selected participants randomly from their student lists. Teachers of students with visual impairments who work in schools for students with visual impairments filled the Social Skills Rating Scale for all of their students except children with a second disability. After teachers of both groups filled the scales, researchers checked the scales. Scales which erroneously had been filled were omitted and a total of 132 participants' data were analysed in the study.

\subsection{Data Collection Instruments}

In this study, the Social Skills Rating Scale and a Personal Information Form were used to collect data. The Social Skills Rating Scale and the Personal Information Form were filled by the teachers of both groups for every participant.

\subsubsection{Social Skills Rating Scale}

The Social Skills Rating Scale Teacher Form is an instrument which is developed by Gresham and Elliot (1990) in order to obtain data from teachers about their 6 to 11 aged students' social skills, problem behaviours and academic competence. Social Skills Rating Scale Teacher Form (Gresham and Elliot, 1990) includes Social Skills Scale, Problem Behaviour Scale and Academic Competency Scale. In this study Social Skills Scale Teacher Form (Gresham and Elliot, 1990) was used to obtain data from teachers regarding their students' social skills.

The Social Skills Rating Scale was translated into Turkish by Sucuoglu and Ozokcu (2005). The Social Skills Rating Scale were applied to 53 mainstream and 560 typically developing children in the original reliability and validity study. Sucuoglu and Ozokcu (2005) established the reliability and validity of the Turkish Form in the study. In the study, the reliability of the scale was tested by calculating Cronbach alpha coefficients. Cronbach alpha coefficient was calculated to be .96 in Social Skills Scale. .96 Cronbach alpha coefficient indicates that Social Skill Scale is a reliable instrument to use.

The Social Skills Scale which was used in the study includes 30 items. The frequency of each item was described on a 3-point Likert scale ranging from 0 (never or rarely), to 1 (often) and to 2 (very often). Higher scores indicate greater social skills related to the item. The importance of the item in school success is described on another 3 point Likert scale ranging from 0 (not important), to 1 (important) and to 2 (critical). There are three sub-scales in Social Skills Scale. These sub-scales are cooperation scale, assertiveness scale and self-control scale. 


\subsubsection{Personal Information Form}

A Personal Information Form was developed by the authors in order to collect various data related to participants. Students' age, gender and grade levels obtained via the Personal Information Form. Through the Personal Information Form, disability status (having a visual impairment or being typically developing) and the degree of visual impairments for students with visual impairments were also obtained. The data obtained from the Personal Information Form was used in the statistical analysis.

\section{RESULTS}

\subsection{Reliability Results Of Social Skills Scale And The Sub-Scales Of Social Skills Scale}

Reliability results of Social Skills Scale and the sub-scales of Social Skills Scale were shown in Table 3.

Table 3. Reliability results of Social Skills Scale and the sub-scales of Social Skills Scale.

\begin{tabular}{|l|c|c|c|}
\hline & $\begin{array}{c}\text { Number of } \\
\text { Items }\end{array}$ & Cronbach Alfa & Reliability Level \\
\hline Social Skills Scale & 29 & 0.947 & Highly Reliable \\
\hline Assertiveness & 10 & 0.913 & Highly Reliable \\
\hline Cooperation & 12 & 0.892 & Highly Reliable \\
\hline Self-Control & 7 & 0.820 & Highly Reliable \\
\hline
\end{tabular}

Reliability analysis for the Social Skills Scale and its sub-scales was conducted using Cronbach alpha coefficient Table 3 shows that reliability analysis indicated that the Social Skills Scale $(\alpha=0,947)$ and assertiveness subscale $(\alpha=0.913)$, cooperation sub-scale $(\alpha=0.892)$ and self-control sub-scale $(\alpha=0.820)$ which were the sub-scales of the Social Skills Scale were highly reliable.

\subsection{Do Social Skills Of Students With Visual Impairments Differ From Their Typically Developing Peers?}

The Social Skills Scale scores of students with visual impairments were compared to their typically developing peers. A Mann Whitney $U$ test was used to examine the differences between students with visual impairments and typically developing peers. The results were shown in Table 4.

Table 4. Comparison of the social skills of students with visual impairments and typically developing students.

\begin{tabular}{|c|c|c|c|c|c|}
\hline $\begin{array}{c}\text { Scale and } \\
\text { Subscales }\end{array}$ & Groups & $\mathbf{N}$ & $\begin{array}{c}\text { Median } \\
\text { (Min-Max.) }\end{array}$ & $\mathbf{Z}$ & $\mathbf{p}$ \\
\hline Assertiveness & SVI & 64 & $14.5(1-20)$ & -4.586 & $0.000^{* * *}$ \\
& TDS & 68 & $18(7-20)$ & & \\
\hline Cooperation & VIS & 64 & $13(1-24)$ & -5.794 & $0.000^{* * *}$ \\
& TDS & 68 & $20(4-24)$ & & $0.000^{* * *}$ \\
\hline Self-control & VIS & 64 & $9(0-14)$ & -5.989 & \\
\hline TDS & TDS & 68 & $11(5-14)$ & & $0.000^{* * *}$ \\
\hline Scale & VIS & 64 & $37(7-55)$ & -6.414 & \\
\hline
\end{tabular}

SVI: Students with visual impairments, TDS: Typically developing students.

${ }^{*}: p<0.05^{* *}: p<0.01^{* * *}: p<0.001$

Table 4 shows that assertiveness $(p<0.001)$, cooperation $(p<0.001)$, self-control $(p<0.001)$, and overall social skills $(p<0.001)$ scores of children with visual impairments were significantly lower than their typically developing peers' scores. 


\subsection{Do Social Skills Of Students With Visual Impairments Differ Significantly In Regard To Their Grade Levels?}

Social skills of students with visual impairments were examined based on their current grade levels. A Kruskal Wallis Test was used to compare the social skills of students based on their grade levels. The results were shown in Table 5.

Table 5. Examination of social skills of students with visual impairments based on students' grade levels.

\begin{tabular}{|c|c|c|c|c|c|c|}
\hline Scale and sub-scales & $\begin{array}{l}\text { Grade } \\
\text { levels }\end{array}$ & $\mathbf{N}$ & $\begin{array}{c}\text { Median } \\
\text { (Min - Max.) }\end{array}$ & $\begin{array}{c}\text { Chi- } \\
\text { Square }\end{array}$ & $\mathbf{p}$ & Difference \\
\hline Assertiveness & $\begin{array}{l}\text { 1.grade } \\
\text { 2.grade } \\
\text { 3.grade } \\
\text { 4.grade } \\
\end{array}$ & $\begin{array}{c}8 \\
18 \\
15 \\
23 \\
\end{array}$ & $\begin{array}{c}8(3-20) \\
16(6-20) \\
13(5-18) \\
13(1-20) \\
\end{array}$ & 9.175 & $0.027^{\star}$ & $2-1,4$ \\
\hline Cooperation & $\begin{array}{l}\text { 1.grade } \\
\text { 2.grade } \\
\text { 3.grade } \\
\text { 4.grade }\end{array}$ & $\begin{array}{c}8 \\
18 \\
15 \\
23 \\
\end{array}$ & $\begin{array}{c}10.5(7-19) \\
15(11-24) \\
12(6-17) \\
12(1-24) \\
\end{array}$ & 4.397 & 0.222 & - \\
\hline Self-control & $\begin{array}{l}\text { 1.grade } \\
\text { 2.grade } \\
\text { 3.grade } \\
\text { 4.grade } \\
\end{array}$ & $\begin{array}{c}8 \\
18 \\
15 \\
23 \\
\end{array}$ & $\begin{array}{c}7(0-11) \\
9.5(7-13) \\
9(4-11) \\
8(2-14) \\
\end{array}$ & 7.199 & 0.066 & - \\
\hline \multirow{3}{*}{ Social Skills Scale } & $\begin{array}{l}\text { 1.grade } \\
\text { 2.grade }\end{array}$ & $\begin{array}{c}8 \\
18\end{array}$ & $\begin{array}{l}23.5(14-50) \\
42(26-55)\end{array}$ & \multirow{3}{*}{9.797} & \multirow{3}{*}{$0.020^{*}$} & \multirow{3}{*}{$1-2$} \\
\hline & 3.grade & 15 & $33(15-44)$ & & & \\
\hline & 4.grade & 23 & $35(7-53)$ & & & \\
\hline
\end{tabular}

${ }^{*}: p<0.05{ }^{* *}: p<0.01^{* * *}: p<0.001$

Table 5 shows that assertiveness and overall social skills scores of students with visual impairments differed significantly based on their grade levels $(p<0.05)$. Cooperation and self-control scores did not differ based on grade level $(p>0.05)$. Assertiveness skills of students with visual impairments who attended the first grade are significantly more than students with visual impairments who attend the first and fourth grade. Overall social skills of the second grader students with visual impairments are significantly higher than social skill scores of children with visual impairments who attend the first grade.

\subsection{Do Social Skills Of Students With Visual Impairments Differs Based On Students' Age?}

Social skills of students with visual impairments were examined based on their age. A Kruskal Wallis Test was used to compare the social skills of students based on their age. The results were shown in Table 6.

Table 6. Examination of social skills of students with visual impairments based on their age.

\begin{tabular}{|l|c|c|c|c|c|c|}
\hline $\begin{array}{l}\text { Scale and sub- } \\
\text { scales }\end{array}$ & Age & $\mathbf{N}$ & $\begin{array}{c}\text { Median } \\
\text { (Min - Max.) }\end{array}$ & $\begin{array}{c}\text { Chi- } \\
\text { Square }\end{array}$ & $\mathbf{p}$ & Difference \\
\hline & 7 & 6 & $11(3-20)$ & & & \\
Assertiveness & 8 & 17 & $16(5-20)$ & & & \\
& 9 & 16 & $14(5-18)$ & 6.382 & 0.172 & - \\
& 10 & 11 & $11(3-20)$ & & & \\
Cooperation & 11 & 14 & $13(1-20)$ & & & \\
& 7 & 6 & $13.5(8-19)$ & & & \\
& 8 & 17 & $15(7-24)$ & & & \\
& 9 & 16 & $13(6-19)$ & 1.876 & 0.759 & \\
\hline & 10 & 11 & $15(6-21)$ & & & \\
Self-control & 11 & 14 & $11,5(1-24)$ & & & \\
& 7 & 6 & $7.5(0-11)$ & & & \\
& 8 & 17 & $10(7-13)$ & 7.223 & 0.125 & \\
& 9 & 16 & $8.5(4-11)$ & & & \\
\hline
\end{tabular}




\begin{tabular}{|l|c|c|c|c|c|c|}
\hline & 11 & 14 & $9(2-14)$ & & & \\
\hline & 7 & 6 & $32.5(14-50)$ & & & \\
Social Skills & 8 & 17 & $42(19-55)$ & & & \\
Scale & 9 & 16 & $36(15-44)$ & 5.807 & 0.214 & - \\
& 10 & 11 & $35(17-48)$ & & & \\
& 11 & 14 & $32(7-53)$ & & & \\
\hline
\end{tabular}

${ }^{*}: p<0.05{ }^{* *}: p<0.01^{* * *}: p<0.001$

Table 6 shows that assertiveness, cooperation and self-control skills and overall social skills scores did not differ based on ages of children with visual impairments ( $p>0.05)$.

\subsection{Do Social Skills Of Students With Visual Impairments Differ Based On Students" Gender?}

Social skills of students with visual impairments were compared based on their gender. A Mann Whitney U test was used to compare the social skills of students based on their gender. The results were shown in Table 7.

Table 7. Comparison of social skills of students with visual impairments based on their gender.

\begin{tabular}{|l|c|c|c|c|c|}
\hline Scale and subscales & Gender & $\mathbf{N}$ & $\begin{array}{c}\text { Median } \\
\text { (Min - Max.) }\end{array}$ & Z \\
\hline Assertiveness & Female & 28 & $16(3-20)$ & -0.855 & 0.392 \\
\hline Cooperation & Male & 36 & $13.5(1-20)$ & \\
\hline Self-control & Female & 28 & $12.5(1-22)$ & -0.679 & 0.497 \\
\hline Social Skills Scale & Male & 36 & $13(4-24)$ & 0.753 \\
\hline & Female & 28 & $9(0-12)$ & -0.314 & \\
\hline & Male & 36 & $8.5(2-14)$ & \\
\hline
\end{tabular}

${ }^{*}: p<0.05^{* *}: p<0.01^{* * *}: p<0.001$

Table 7 shows that the assertiveness, cooperation, self-control skills and overall social skills scores of students with visual impairments did not differ significantly based on their genders ( $p>0.05)$.

\subsection{Do Social Skills Of Students With Visual Impairments Differ Based On The Degree Of Visual Impairments?}

Social skills of students with visual impairments were compared based on the degree of visual impairments. A Mann Whitney $U$ test was used to compare the social skills of students based on the degree of visual impairments. The results were shown in Table 8.

Table 8. Comparison of social skills of students with visual impairments based on the degree of visual impairments.

\begin{tabular}{|l|c|c|c|c|c|}
\hline Scale and subscales & Degree of VI & $\mathbf{N}$ & $\begin{array}{c}\text { Median } \\
\text { (Min - Max.) }\end{array}$ & $\mathbf{Z}$ & $\mathbf{p}$ \\
\hline Assertiveness & SLW & 34 & $13(1-20)$ & -0.614 & 0.539 \\
\hline Cooperation & SSW & 30 & $15(3-20)$ & & \\
\hline
\end{tabular}


IJAEDU- International E-Journal of Advances in Education, Vol. 2, Issue 4, April 2016

\begin{tabular}{|l|c|c|c|c|c|}
\hline \multirow{2}{*}{ Self-control } & SSW & 30 & $13(1-22)$ & & \\
\hline \multirow{2}{*}{ Social Skills Scale } & SLW & 34 & $8,5(2-14)$ & -0.876 & 0.381 \\
\cline { 2 - 6 } & SSW & 30 & $9(0-13)$ & & \\
\hline
\end{tabular}

${ }^{*}: p<0.05^{* *}: p<0.01^{* * *}: p<0.001$

VI: Visual impairments, SLW: Students with low vision, SSW: Students with severe visual impairments.

Table 8. shows that the assertiveness, cooperation, self-control skills and overall social skills scores of students with visual impairments do not differ significantly based on their degree of visual impairments (students with low vision or students with severe visual impairments) $(p>0.05)$.

\section{DISCUSSION}

The main purpose of this study was to compare the social skills of students with visual impairments with typically developing peers. Study results showed that both social skills and sub-scale scores of students with visual impairments were significantly lower than their typically developing peers. Ozkubat and Ozdemir (2012) compared the social skills of students with visual impairments and typically developing peers. Results of the study showed that social skills of students with visual impairments were significantly lower than their typically developing peers' social skills. Other studies conducted in Turkey in regard to social skills of students with visual impairments also indicated that students with visual impairments have limited social skills when compared to their typically developing peers (Ozdemir, 2009; Ozdemir \& Ataman, 2010; Ozdemir et al., 2011). Current study findings in regard to the social skills of students with visual impairments are consistent with the other study results conducted in Turkey. Studies from different cultures that examine the social skills of students with visual impairments also indicated some differences between students with visual impairments and their peers (Buhrow et al., 1998).

The findings of the current study indicated that social skills of students with visual impairments did not differ based on the participants' age or gender. Different findings have been found in the literature related to the age factor. While some studies showed students' social skills differed based on students' age (Gunes, 2008; Hocaoglu, 2009), some studies showed that the age was not a significant factor in social skills development (Tuy, 1999). Researchers discuss that in general when ages of students increase, their social skills increase as well. In contrast to these findings, Ozkubat and Ozdemir (2012) found that the age was not a significant factor in improving social skills of students with visual impairments. The findings of the current study indicate that the age was not a significant factor in social skills of students with visual impairments.

Another issue in examining social skills is participants' gender. Ozkubat and Ozdemir (2012) reported that social skills of female students with visual impairments were significantly higher than their male peers' social skills. Sucuoğlu and Ozokcu (2005) also found that female students with special needs had improved social skills than male students with special needs. When considering cultural and social roles related to different genders in Turkish culture, one may consider these results as a reflection of cultural norms and social roles expected from female students. On the other hand, some researchers found that gender was not a significant factor in social skills of students (Arslan, 2013; Aykir \& Ciftci-Tekinarslan, 2012). In the current study, gender was found to have no significant effect on social skills of students with visual impairments as well.

Another factor which was explored in the study related to social skills of students with visual impairments was effects of the degree of visual impairments. While students with low vision use their sense of vision partially, students with severe visual impairments do not use sense of vision and depend on their sense of touch predominantly. It is possible to form a hypothesis that may argue that students with low vision would have higher social skills than students with severe visual impairments. Having sense of partial vision may affect social skills development positively. However, the current study findings showed that having low vision had no effect on social skills of students with visual impairments. The reason of this finding could be that students with visual impairments in the current study shared the same educational environment with their peers with severe visual impairments in a restricted school for students with visual impairments.

Overall results of the current study showed that children with visual impairments had lover social skills than their typically developing peers. Other studies conducted in Turkey reported similar results as well. The 
current study findings are important to suggest the social needs of students with visual impairments. This current study and the other similar studies are important in order to provide evidence base for the risk of social skills problems of students with visual impairments.

\subsection{Recommendations For Future Research And Practice}

The current study is an important study that indicates the social skills problems of students with visual impairments in Turkey. However, more comprehensive studies could be greater benefit to the field. Different data collection techniques to obtain social skills data of students with visual impairments can be used. For example, direct observations, parent and student interviews may be used to collect study data. In this study, the Social Skills Rating Scale Teacher Form was used to collect the data.

In the current study, a total of 132 students with visual impairments' social skills data were examined. Studies with larger participant groups may provide more comprehensive results.

The current study is also important for teachers and other professionals who work with students with visual impairments. The findings of the study stress the need for social skills interventions for students with visual impairments. Therefore, a national curriculum that guides teachers of students with visual impairments is needed.

Screening social skills problems of students with visual impairments as early as possible is also critical to intervene social problems as early as possible. In order to achieve this, regular screening protocols should be developed and used in schools. Screening for social skill problems may provide necessary information about the social skills needs of students with visual impairments.

\section{REFERENCE LIST}

Aykir, T., \& Cifci-Tekinarslan, I. (2012). Okul öncesi dönemde bulunan zihin yetersizliği olan ve olamayan çocukların sosyal becerileri ve problem davranışlarının karşılaştıııması. Kastamonu Üniversitesi Eğitim Fakültesi Dergisi, 20 (2), 627-648.

Arslan, İ.M. (2013). İş okuluna devam eden ve etmeyen eğitilebilir öğrencilerin sosyal beceri düzeylerinin karşılaştırılması. Unpublished master's thesis, Yeditepe Üniversitesi Eğitim Bilimleri Enstitüsü, İstanbul.

Avcıoglu, H. (2005) Etkinliklerle Sosyal Beceri Öğretimi. Ankara: Kök Yayıncılık.

Bacanlı, H. (1999). Sosyal Beceri Öğretimi. Ankara: Nobel Yayın Dağıtım.

Buhrow, M. M., Hartshorne, Timony, S., \& Bradley-Johnson, S. (1998). Parents and teachers ratings of the social skills of elementary-age students who are blind. Journal of Visual Impairment and Blindness, 92(7), 213-227.

Bandura, A. (1986). Social Foundations of Thought and Action. Englewood Cliffs, NJ: Prentice Hall.

Caldarella, P., \& Merrell, K. W. (1997). Common dimensions of social skills of children and adolescents: A taxonomy of positive behaviors. School Psychology Review, 26(2), 264-278.

Ceylan, Ş. (2009). Vineland Sosyal - Duygusal Erken Çocukluk Ölçeğinin Geçerlilik Güvenilirlik Çalışması ve Okul Öncesi Eğitim Kurumuna Devam Eden Beş Yaş Çocuklarının Sosyal - Duygusal Davranışlarına Yaratıcı Drama Eğitiminin Etkisinin İncelenmesi. Unpublished doctoral dissertation, Gazi Üniversitesi Eğitim Bilimleri Enstitüsü, Ankara.

D'Allura, T. (2002). Enhancing the social interaction skills of preschoolers with visual impairments. Journal of Visual Impairment and Blindness, 96, 576-584.

Dodge, K. A., \& Murphy, R. (1984). The assessment of social competence in adolescents. In Karoly, P., \& Steffen, J. J. (Ed.), Adolescent Behavior Disorders: Foundations and Contemporary Concerns (pp. 6196). Lexington, MA: Lexington Books.

Farkas, G. M., Sherick, R. B., Matson, J.L., \& Loebig, M. (1981). Social skills training of a blind child through differential reinforcement. Behaviour Therapist, 4, 24-26.

Gunes, G. (2008). 4-6 Yaş Zihin Engelli Çocukların Davranış Sorunlarının İncelenmesi. Unpublished master's thesis, Marmara Üniversitesi Eğitim Bilimleri Enstitüsü, İstanbul.

Harrel, R. L., \& Strauss, F. A. (1986). Aproaches to increasing assertive behavior and communication skills in blind and visually impaired persons. Journal of Visual Impairment and Blindness, 80, 794-798. 
Hocaoglu, A. (2009). Zihinsel Engelli Ergenlerin Okul İçi Sosyal Yeterlilik Düzeyleri ve Problem Davranışları İle Anne-Babalarının Sosyal Beceri Düzeylerinin Karşılaştııılarak İncelenmesi. Unpublished master's thesis, Marmara Üniversitesi Eğitim Bilimleri Enstitüsü, İstanbul.

Ladd, G. W. (1999). Peer relationships and social competence during early and middle childhood. Annual Review of Psychology, 50, 333-359.

McAlpine, L. M., \& Moore, C. L. (1995). The development of social understanding in children with visual impairments. Journal of Visual Impairment and Blindness, 89, 349-358.

McGuire, J., \& Priestly, P. (1981). Life after school: A Social Skills Curriculum. Pergamon Press: Oxford.

Merrell. K., \& Gimpel. G. A. (1998). Social Skills of Children and Adolescents: Conceptualization, Assessment, Treatment. Mahwah. NJ: Lawrence Erlbaum Associates. Retrieved from http://samples.sainsburysebooks.co.uk/9781317778493 sample 488267.pdf on 8.01.2015.

Ozdemir, S. (2009). Görme yetersizliği olan cocuklar ile tipik gelisim gösteren çocukların sosyal becerilerinin karşılaştırılması. Paper presented at 19. Ulusal Ozel Eğitim Kongresi, Marmaris, Muğla.

Ozdemir, S. (2010). Sosyal becerilerin ve sosyal uyumun desteklenilmesi (Suppporting social skills and social functioning of inclusive education students). In Diken, H. İ. (ed.) Kaynastirma (Inclusion). Ankara: Pegem Akademi.

Ozdemir, S., Gurel, O., Ceyhun, A.T., Sahin, R., \& Küçüközyiğit, M. S. (2011). Okul öncesi dönemde görme engelli çocuklarla normal gelişim gösteren çocukların oyun davranışlarının karşılaştırılması, Paper presented at 21. Ulusal Özel Eğitim Kongresi, Kıbrıs.

Ozdemir, S. (2013). Duygu Davranış Bozukluğu Olan Öğrenciler. In Diken, H. İ., Özel Eğitime Gereksinimi Olan Öğrenciler ve Özel Eğitim İçinde. Pegem Akademi: Ankara.

Ozdemir, S., \& Ataman, A. (2010). Görme yetersizliğinden etkilenen çocukların sosyal beceri yetersizliği. Paper presented at 20. Ulusal Ozel Eğitim Kongresi, Gaziantep.

Ozkubat, U., \& Ozdemir, S. (2012). Görme yetersizliğinden etkilenmiş ve normal gelişim gösteren çocukların sosyal becerilerinin karşılaştırılması. Ankara Üniversitesi Özel Eğitim Dergisi, 13(1), 1-14.

Raver, S. (1984). Modification of head droop during conversation in a 3-year-old visually impaired child: A case study. Journal of Visual Impairment \& Blindness.

Strain P.S., \& Odom S.L., (1986). Peer social initiations: effective intervention for social skills development of exceptional children. Exceptional Children, 52(6), 543-551.

Sucuoğlu, B., \& Özokçu, O. (2005). Kaynaştırma öğrencilerinin sosyal becerilerinin değerlendirilmesi. Ankara Üniversitesi Eğitim Bilimleri Fakültesi Özel Eğitim Dergisi, 6(1), 41-57.

Tuy, S. (1999). 3-6 Yaş Arasındaki İşitme Engelli ve Işiten Çocukların Sosyal Becerileri ve Problem Davranışları Yönünden Karşılaştırılmaları. Unpublished master's thesis, Ankara Üniversitesi Sosyal Bilimler Enstitüsü, Ankara. 